\title{
Role of Human Factor VIII in Factor X Activation
}

\author{
Mae B. Hultin, Division of Hematology, Department of Medicine, State \\ University of New York, Stony Brook, New York 11794, and Veterans \\ Administration Medical Center, Northport, New York 11768
}

A B S T R A C T The cofactor function of human Factor VIII in Factor $\mathrm{X}$ activation was investigated by an initial-rate assay of ${ }^{3} \mathrm{H}$-Factor $\mathrm{X}$ activation in the presence of human factor $\mathrm{IXa}, \mathrm{Ca}^{2+}$, and either phospholipid or fresh washed human platelets. Purified Factor VIII that has not been activated by thrombin or Factor $X a$ supports Factor $X$ activation after a lag of several minutes. A specific inhibitor of Factor $\mathrm{Xa}$, which had no inhibitory activity against Factor IXa, markedly prolonged this lag, whereas specific thrombin inhibitors did not prolong the lag. These data support the conclusion that unactivated Factor VIII has no ability to support Factor $\mathrm{X}$ activation in a purified system until it is activated by Factor Xa feedback during the lag period. When Factor VIII was optimally preactivated by thrombin, the lag was completely abolished, regardless of the order of addition of the other reactants or the phospholipid source. These data indicate that there is no slow, time-dependent ordering of the reactants at the phospholipid or activated platelet surface if Factor VIII has been preactivated. Unactivated platelets did not support Factor $\mathrm{X}$ activation by Factors IXa and VIII. The effect of activated Factor VIII on the kinetics of bovine Factor $\mathrm{X}$ activation was primarily to increase the $\mathrm{V}_{\max }$ (54-fold), whereas with human Factor $X$, Factor VIII both increased the $V_{\max }$ 56 -fold and decreased the $K_{\mathrm{m}}$ sixfold to $0.14 \mu \mathrm{M}$, similar to the plasma concentration of Factor $X$. Therefore, a change in the plasma factor $X$ concentration would be expected to have a major effect on the rate of Factor $\mathrm{X}$ activation in vivo.

\section{INTRODUCTION}

Factor VIII is a plasma glycoprotein that acts as a cofactor to the enzyme Factor IXa in the activation of Factor $X$ by the intrinsic pathway of blood coagulation (1-4). Previous studies have suggested that

Received for publication 28 November 1980 and in revised form 30 November 1981. native Factor VIII has little or no cofactor activity until modified in some fashion by thrombin $(4,5)$. In vitro, thrombin activates Factor VIII 10-fold to 100fold; Factor Xa has also been shown to activate Factor VIII (6). We (4) showed that thrombin-activated Factor VIII supported Factor $\mathrm{X}$ activation with a slight lag of 15-30 s, whereas unactivated Factor VIII supported Factor $\mathrm{X}$ activation weakly only after a 2- to 3-min lag. The lag with unactivated Factor VIII was lengthened by the inhibitor benzamidine, suggesting that the ability of unactivated Factor VIII to support Factor $\mathrm{X}$ activation was dependent on activation of Factor VIII by Factor Xa or thrombin during the lag. We also hypothesized that the short lag seen with activated Factor VIII reflected a time-dependent ordering of the reactants in the lipid matrix.

I have now performed further studies to test these hypotheses. These studies show that unactivated Factor VIII does not support Factor $\mathrm{X}$ activation and that the lag can be completely abolished when Factor VIII has been previously activated. I also studied the effect of activated Factor VIII on the kinetic parameters of bovine and human Factor $\mathrm{X}$ activation. For bovine Factor $X$, the effect was primarily on the maximum velocity $\left(V_{\max }\right)$, with little effect on the Michaelis constant $\left(K_{\mathrm{m}}\right)$; with human Factor $\mathrm{X}$, there was an effect on the $V_{\max }$ and also on the $K_{\mathrm{m}}$. I also investigated the role of platelets in Factor $\mathrm{X}$ activation by Factors IXa and activated VIII. I found that thrombin-activated platelets, but not unactivated platelets, supported Factor $\mathrm{X}$ activation as well or better than various phospholipid suspensions. The implications of these findings for the mechanism of Factor VIII cofactor activity are discussed.

\section{METHODS}

Coagulation assays. The assays of Factors VIII, IX, and IXa were performed as previously reported (4). Human Factor VIII-deficient plasma $(<0.01 \mathrm{U} / \mathrm{ml})$, Factor IX-deficient plasma, and pooled normal human plasma were purchased from George King Biomedical, Overland Park, KA.

Protein purification. Human Factor VIII concentrate 
(Hemofil) for Factor VIII purification was kindly supplied by Dr. William Thomas, Hyland Diagnostics Div., Travenol Laboratories, Inc., Costa Mesa, CA. Factor VIII was purified as previously reported (4), with the modification that aprotinin, $100 \mathrm{U} / \mathrm{ml}$, was added to Factor VIII before chromatography on Biogel A15m (Bio-Rad Laboratories, Richmond, $\mathrm{CA})$ and that the eluting buffer contained aprotinin, $5 \mathrm{U} /$ $\mathrm{ml}$. This resulted in a better yield, with $40 \%$ of the applied Factor VIII units eluting in the void volume with a specific activity of $25 \mathrm{U} / \mathrm{mg}$. The $\mathrm{V}_{\text {o }}$ peak was pooled and analyzed by $5 \%$ sodium dodecyl sulfate polyacrylamide gel electrophoresis (SDS-PAGE) ${ }^{1}$ (7); unreduced, the protein did not enter the $5 \%$ gel, but after reduction with $2 \% \beta$-mercaptoethanol, a 200,000-mol wt band was seen. This purified factor VIII could be activated more than 20 -fold by thrombin and was stable for at least $8 \mathrm{~h}$ at $4^{\circ} \mathrm{C}$ in $0.10 \mathrm{M} \mathrm{NaCl}, 0.05 \mathrm{M}$ Tris, pH 7.4 (Tris-buffered saline, TBS), $1.0 \%$ bovine serum albumin. It was stored in small aliquots at $-70^{\circ} \mathrm{C}$ in plastic tubes. No contaminating proteases could be detected in the Factor VIII preparation in TBS-bovine serum albumin by assay for amidase activity on S-2238 at $0.1 \mathrm{mM}(<0.01 \mathrm{nM}$ thrombin), S-2251 at $0.6 \mathrm{mM}$ ( $<0.01$ Committee on Thrombolytic Agents U/ml plasmin), S-2222 at $0.5 \mathrm{mM}$ $(<0.03 \mathrm{nM}$ Factor $\mathrm{Xa})$, and S-2160 at $0.4 \mathrm{mM}(<0.2 \mathrm{nM}$ activated protein C [8]) (Ortho Diagnostics, Raritan, NJ) (9). Purified human $\alpha$-thrombin $(2,914$ National Institutes of Health U/mg) was a gift of Dr. John Fenton, Albany, NY.

Bovine Factor $\mathrm{X}$ was purified and tritiated as previously reported (10) to a specific activity of $26,400 \mathrm{cpm} / \mu \mathrm{g}$. Bovine Factor Xa was the gift of Dr. Jolyon Jesty, Stony Brook, NY. Human Factors IX and X were purified from Factor IX concentrate (kindly supplied by Cutter Laboratories, Inc., Berkeley, CA) by barium citrate absorption and elution, heparin agarose chromatography, benzamidine-agarose chromatography, and hydroxyapatite chromatography. Analysis of the purification and activation on $10 \%$ SDS-PAGE gels by a modification of the method of Laemmli (11) showed a single band of $56,000 \mathrm{~mol}$ wt for Factor IX; this singlechain protein was converted to a $46,000-\mathrm{mol}$ wt two-chain protein upon activation. Human Factor IXa was prepared by activation of purified human Factor IX with human Factor XIa (a gift of Dr. Allen Kaplan, Stony Brook, NY) at a 65:1 (mol $/ \mathrm{mol})$ substrate/enzyme ratio, at $37^{\circ} \mathrm{C}$ in TBS, 8 $\mathrm{mM} \mathrm{Ca}{ }^{2+}$, for $2 \mathrm{~h}(12)$. The protein concentration of the Factor IXa preparation was determined by OD at $280 \mathrm{~nm}$, assuming an $\mathrm{A280}^{1 \%}$ of 13.3 . Factor XIa was not routinely removed from the Factor IXa preparation, since control experiments showed that the trace of Factor XIa present (e.g., $0.03 \mathrm{nM}$ at $2 \mathrm{nM}$ Factor IXa) had no measurable effect on the activation of Factor X by Factors IXa and VIII. The molar concentration of Factor IXa in this preparation was determined by titration against purified bovine antithrombin III (the gift of Dr. Jolyon Jesty, Stony Brook, NY) in heparin, $0.05 \mathrm{U} / \mathrm{ml}$. By these assays, the total protein concentration was $330 \mu \mathrm{g} / \mathrm{ml}$ with a factor IXa content of $250 \mu \mathrm{g} / \mathrm{ml}$, or $75 \%$ of the protein, in agreement with the SDS-PAGE analysis; the remainder of the protein was presumed to be un-

${ }^{1}$ Abbreviations used in this paper: BZA, benzamidine; DAPA, dansyl arginine $N$-(3-ethyl-1,5pentanediyl)amide; IGGA-CK, Ile-Glu-GLy-Arg- $\mathrm{CH}_{2} \mathrm{Cl}-2 \mathrm{HCl}$; $\mathrm{Pr}_{2} \mathrm{PF}$, diisopropylfluorophosphate; PC, phosphatidylcholine; PMSF, phenylmethylsulfonyl fluoride; PS, phosphatidylserine; SDSPAGE, sodium dodecyl sulfate polyacrylamide gel electrophoresis; STI, soybean trypsin inhibitor; TBS, Tris-buffered saline. activated Factor IX on the basis of the SDS-PAGE analysis. These results were also supported by comparison of this Factor IXa preparation with a reference human Factor IXa, kindly supplied by Dr. David Aronson, Bethesda, MD. Purified human Factor $X$ showed a single band of 57,000 apparent mol wt when unreduced, and two bands when reduced on Laemmli gels. Tritiation of human Factor $\mathrm{X}$ was performed similarly to that for bovine Factor $X$, except that the time of oxidation was reduced to $10 \mathrm{~min}$ to retain biologic activity (at least $75 \%$ ), with a sp act of $47,900 \mathrm{cpm} / \mu \mathrm{g}$. Human Factor $X$ was activated by incubation with purified coagulant protein from Russell's viper venom (the gift of Dr. J. Jesty).

Factor IXa inhibition studies. The effects of inhibitors on human Factor IXa were studied in the Factor IXa assay, which measured the initial rate of Factor $X$ activation using tritiated Factor X (4); the assay was modified by making Factor IXa the final addition, so that possible effects of each inhibitor on thrombin activation of Factor VIII did not confuse interpretation of the assay. This was accomplished by incubating Factor VIII (1-5 U/ml, inosithin $(60 \mu \mathrm{g} / \mathrm{ml}),{ }^{3} \mathrm{H}$ Factor $\mathrm{X}(0.26 \mu \mathrm{M})$, thrombin $(0.012 \mathrm{U} / \mathrm{ml})$, and $\mathrm{Ca}^{2+}(9$ $\mathrm{mM})$ at $37^{\circ} \mathrm{C}$ for $3 \mathrm{~min}$ and then adding Factor IXa (2-7 $\mathrm{nM}$ ) that had been incubated separately with inhibitor or TBS. The initial rate of Factor $X$ activation, as judged by the slope of the linear plot of tritiated peptide release during the first minute of activation, was determined for the Factor IXa control in TBS vs. Factor IXa in inhibitor. Because this Factor IXa assay has a coefficient of variation of $5 \%$, an inhibitor was considered to lack effect on Factor IXa if the assay of Factor IXa in the inhibitor was within $5 \%$ of the control assay in duplicate experiments. Dansyl arginine $N$ (3-ethyl-1,5-pentanediyl) amide (DAPA) was the gift of Dr. Michael Nesheim and Dr. Kenneth Mann, Mayo Clinic, Rochester, MN. The oligopeptide chloromethyl ketone inhibitor Ile-Glu-Gly-Arg- $\mathrm{CH}_{2} \mathrm{Cl}-2 \mathrm{HCl}$ (IGGA-CK) was generously provided by Dr. Charles Kettner, Brookhaven Laboratories, Brookhaven, NY. Diisopropylfluorophosphate $\left(i r_{2} P F\right)$, phenylmethyl-sulfonyl fluoride (PMSF), soybean trypsin inhibitor (STI), hirudin, and Trizma base were purchased from Sigma Chemical Co., St. Louis, MO. Benzamidine hydrochloride was purchased from Aldrich Chemical Co., Inc., Milwaukee, WI, and inosithin from Associated Concentrates, Woodside, NY. For competitive reversible inhibitors (benzamidine, DAPA), the inhibitor concentration in the final assay mixture, not in the incubation with Factor IXa, was considered the effective concentration, as listed in Table I. For inhibitors that are irreversible, and in some cases time dependent, under the experimental conditions (iPr ${ }_{2} \mathrm{PF}, \mathrm{PMSF}, \mathrm{STI}$, hirudin), the inhibitor was incubated at $37^{\circ} \mathrm{C}$ for different periods of time with Factor IXa, as detailed in Table $I$, and the effective inhibitor concentration was considered to be that in the incubation mixture with Factor IXa. In addition, to study the effect of $\mathrm{iPr}_{2} \mathrm{PF}$, Factor IXa was dialyzed overnight against $0.4 \mathrm{M}$ Tris-Cl, $\mathrm{pH}$ 8.0. The dialyzed Factor IXa was then incubated at $37^{\circ} \mathrm{C}$ with and without $5 \mathrm{mM}^{\mathrm{iPr}} \mathrm{Pr}_{2} \mathrm{PF}$ for $24 \mathrm{~h}$. Under these conditions, the $\mathrm{pH}$ remains $>7.7$ over the 24 -h period.

Thrombin and Factor $\mathrm{Xa}$ inhibition studies. The inhibitory effect of STI $(20 \mu \mathrm{g} / \mathrm{ml})$, IGGA-CK $(1.0 \mu \mathrm{M})$, hirudin $(50 \mathrm{U} / \mathrm{ml})$, or DAPA $(2.0 \mu \mathrm{M})$ on human thrombin $(0.1 \mathrm{nM})$ or Factor $\mathrm{Xa}(0.4 \mathrm{nM})$ was measured by chromogenic substrate assays with S-2238 $(0.05 \mathrm{mM})$ or S-2222 $(0.9 \mathrm{mM})$, respectively (9). Thrombin or Factor $\mathrm{Xa}$ was incubated with each inhibitor or phosphate buffer $(50 \mathrm{mM}$ phosphate, $0.2 \%$ ovalbumin, $\mathrm{pH} 7.5$ ) for $5 \mathrm{~min}$ at $37^{\circ} \mathrm{C}$ and then residual enzyme assayed by the initial rate method in an Acta CIII 
recording spectrophotometer (Beckman Instruments, Inc., Fullerton, CA). A reference curve of human thrombin (0.01$0.18 \mathrm{nM}$ ) in phosphate buffer was assayed and used to calculate residual thrombin activity with a lower limit of sensitivity $<0.006 \mathrm{nM}$. Residual Factor Xa activity was calculated by calibration against a reference curve of purified bovine Factor $\mathrm{Xa}(0.1-1.6 \mathrm{nM})$ in phosphate buffer, with a lower limit of sensitivity $<0.025 \mathrm{nM}$ ). Lack of inhibition was defined as $>90 \%$ residual activity compared to buffer control.

Studies on unactivated Factor VIII. Purified human Factor VIII (the pooled $V_{\text {o }}$ peak from Biogel A-15m chromatography), which was at least 20 -fold activatable by thrombin at $10-20 \mathrm{mU} / \mathrm{ml}$, was used as the source of unactivated Factor VIII, although it is not possible to be certain that it is entirely unactivated. When incubated with Factor $\mathrm{IXa},{ }^{3} \mathrm{H}$-Factor $\mathrm{X}$, inosithin, and $\mathrm{Ca}^{2+}$, there consistently was a lag of at least 2-4 min before Factor $X$ activation was measurable. Factor $X$ activation in the presence of this unactivated factor VIII was measured and compared to the Factor $X$ activation in the presence of an inhibitor of thrombin or Factor Xa that did not inhibit Factor IXa (DAPA, hirudin, STI, or IGGA-CK); the control (without inhibitor) and inhibitor experiments were performed consecutively on the same day with the same reagents and were repeated two to three times on other occasions, with the order of the experimental parts varied, so as to control for any possible time-dependent change in the reagents over the 30-60 min necessary to perform the experiment. Control experiments were also performed in which subsamples were removed for $\mathrm{S}-2222, \mathrm{~S}-2238$, and ${ }^{3} \mathrm{H}-\mathrm{Factor}-\mathrm{X}$ activation assays before, and at $8 \mathrm{~min}$ after, the final addition of $\mathrm{Ca}^{2+}$, in the presence and absence of hirudin $(50 \mathrm{U} / \mathrm{ml})$ or STI $(20 \mu \mathrm{g} / \mathrm{ml})$.

The ability of thrombin to activate Factor VIII in the presence of STI was tested by adding thrombin $(0.04 \mathrm{U} / \mathrm{ml})$ at $2 \mathrm{~min}$ after the final addition of $\mathrm{Ca}^{2+}$ to the mixture of unactivated Factor VIII, Factor IXa,${ }^{3} \mathrm{H}$-Factor $X$, inosithin, and STI $(20 \mu \mathrm{g} / \mathrm{ml})$, with and without DAPA, $2.0 \mu \mathrm{M}$, and hirudin, $100 \mathrm{U} / \mathrm{ml}$. The ability of Factor $\mathrm{Xa}$ to activate Factor VIII and shorten the lag in Factor X activation was tested by incubating bovine Factor Xa $30 \mathrm{ng} / \mathrm{ml}$, with Factor VIII, ${ }^{3} \mathrm{H}-\mathrm{Factor} \mathrm{X}, \mathrm{Ca}^{2+}$, and inosithin for $2 \mathrm{~min}$ before the final addition of Factor IXa and measuring the subsequent activation of Factor $X$. Control experiments were performed identically, except for either the omission of Factor VIII or Factor Xa, or the addition of STI, $20 \mu \mathrm{g} / \mathrm{ml}$.

Studies on the lag in Factor $X$ activation. These studies were aimed at determining whether the apparent lag in Factor $X$ activation could be abolished by changing some variable in the activation and whether the lag was dependent on the order of addition of the reactants in the mixture. For the first goal, Factor $X$ activation was studied in the presence of Factor VIII that was preactivated with increasingly higher concentrations of thrombin, in an attempt to ensure that the Factor VIII was fully activated before the final addition of $\mathrm{Ca}^{2+}$ to the activation mixture. For the second goal, the order of addition of the reactants was varied so that each of the five $\left(\mathrm{Ca}^{2+}\right.$, inosithin or activated platelets, activated Factor VIII, Factor IXa, and Factor X) was absent from the incubation mixture; after a subsample for scintillation counting was taken for the "zero time point," representing no activation, the final reactant was added to the reaction, and timed subsamples were taken for scintillation counting every $15 \mathrm{~s}$ for 1.0-1.5 min. Only the linear portion of the plot of counts per minute vs. time was used (generally the 15-, $30-, 45-$, and 60 - s subsamples), and the slope and $y$ intercept of this linear plot and their standard deviations were cal- culated using a weighted least-squares program, excluding the zero time point, on a Minc II minicomputer (Digital Equipment Corp., Maynard, MA). The counts per minute at zero time was in all cases $<3 \%$ of the total counts per minute in the experiment, which is the usual "base line" trichloroacetic acid-soluble fraction by this technique (10). If the counts per minute measured at zero time was within the 2-SD range of the predicted $y$ intercept, this was considered evidence that no measurable lag was present (Tables II and III). Given these 2-SD limits, a lag of 1-2 $s$ or less might not be detected by these experiments. A zero time point could not be determined experimentally when tritiated Factor $\mathrm{X}$ was the final addition, because the zero time point requires the presence of the tritium label in the mixture. Therefore, the predicted $y$ intercept for this part was compared to the mean of the four zero time points of the other parts performed on the same day with identical reagents. When Factor VIII or platelets was the final addition, each was activated separately with thrombin and added last, so that the final concentrations of platelets, Factor VIII, and thrombin, and the duration of activation with thrombin, were the same in all five experimental parts.

Preparation of fresh washed platelets. Platelets for these experiments were prepared on the same day from 5-10 ml of fresh human blood obtained by venipuncture and anticoagulated with $1 / 100$ vol of $40 \%$ sodium citrate. Plateletrich plasma was prepared by centrifugation at $1,800 \mathrm{rpm}$ for $3.5 \mathrm{~min}$ at $22^{\circ} \mathrm{C}$. The platelets were pelleted by centrifugation and resuspended and washed three times with $10 \mathrm{ml}$ of TBS, $0.1 \mathrm{mM} \mathrm{Na} \mathrm{NaDTA}_{4}$. The final platelet pellet was resuspended in the same buffer, and the volume adjusted to give a platelet count of $1 \times 10^{6} / \mathrm{mm}^{3}$. This platelet suspension showed minimal platelet shape change and clumping by phase microscopy; lower concentrations of $\mathrm{Na}_{4}$ EDTA in the wash buffer did not prevent platelet clumping sufficiently. These unactivated platelets did not support Factor $X$ activation when substituted for inosithin. However, thrombin-activated platelets did support Factor $\mathrm{X}$ activation; $\mathbf{m a x}$ imal factor $\mathrm{X}$ activation was obtained when platelets (at least $0.4 \times 10^{6} / \mathrm{mm}^{3}$ ) were activated with $0.5 \mathrm{U} / \mathrm{ml}$ of thrombin or higher, for $2-3 \mathrm{~min}$ at $37^{\circ} \mathrm{C}$; the observed initial rates were equal to or greater than those with inosithin or cephalin. Platelets washed in higher concentrations of $\mathrm{Na}_{4}$ EDTA ( $1 \mathrm{mM}$ ) supported Factor $\mathrm{X}$ activation poorly under these conditions. Platelets washed in TBS in prostaglandin $E_{1}$ $(10 \mu \mathrm{M})$ (Sigma Chemical Co.) in place of $\mathrm{Na}_{4}$ EDTA did not clump but also did not support ${ }^{3} \mathrm{H}$-Factor $\mathrm{X}$ activation by Factors IXa and VIII. These platelets showed $>90 \%$ inhibition of the release reaction in the presence of thrombin $(0.5 \mathrm{U} / \mathrm{ml})$ as measured by $\left[{ }^{14} \mathrm{C}\right]$ serotonin release $(13)$.

Kinetic studies of Factor $X$ activation. The initial velocity ( $v$ ) of Factor $X$ activation was measured at various Factor $X$ concentrations, both in the presence and absence of activated Factor VIII, with either activated platelets or inosithin and with constant Factor IXa and $\mathrm{Ca}^{2+}$ concentrations. The ${ }^{3} \mathrm{H}$-Factor $\mathrm{X}$ activation assays were performed by the following protocol: fresh washed platelets $\left(0.4-0.5 \times 10^{6} /\right.$ $\left.\mathrm{mm}^{3}\right)$ or inosithin $(60 \mu \mathrm{g} / \mathrm{ml})$, was incubated with human thrombin $(0.5 \mathrm{U} / \mathrm{ml})$ and bovine ${ }^{3} \mathrm{H}$-Factor $\mathrm{X}(0.05-0.5 \mu \mathrm{M})$ at $37^{\circ} \mathrm{C}$ for a total of $3 \mathrm{~min}$; at $2 \mathrm{~min}$ of incubation, human Factor VIII $(4 \mathrm{U} / \mathrm{ml})$, human Factor IXa $(2.0 \mathrm{nM})$, and IGGA-CK $(0.2 \mu \mathrm{M})$ were added, a zero-time subsample was removed, and the final addition of $\mathrm{Ca}^{2+}(8 \mathrm{mM})$ was made at $3 \mathrm{~min}$, followed by timed serial subsampling for scintillation counting of the activation peptides. In experiments with human ${ }^{3} \mathrm{H}$-Factor $\mathrm{X}$, purified phosphatidylserine-phosphatidylcholine (PS-PC) vesicles $(60 \mu \mathrm{g} / \mathrm{ml})$ were substituted 
for inosithin, because PS-PC was found to support faster initial rates of Factor $X$ activation than inosithin. Synthetic PS (100\% dioleoyl) and bovine PC (32\% dioleoyl, 9\% stearyl, 7\% palmitoleoyl, and $44 \%$ palmityl) were purchased from Supelco, Inc., Bellefonte, PA. In the presence of activated Factor VIII, initial rates were determined by subsampling every $15 \mathrm{~s}$ in the first minute after $\mathrm{Ca}^{2+}$ addition. In the absence of Factor VIII, initial rates were extremely slow, and subsampling over $20-40 \mathrm{~min}$ was necessary to determine initial rates accurately. Because activated platelets were not stable over such long time-courses, it was not possible to study the kinetics of Factor $X$ activation with activated platelets in the absence of Factor VIII. The kinetic parameters $K_{\mathrm{m}}$ and $\mathrm{V}_{\max }$ were determined by linear regression analysis of Lineweaver-Burk plots, $\left(\frac{1}{v} v s . \frac{1}{[s]}\right)$ and Eadie plots, (v vs. $\frac{v}{[s]}$ ). Linear regression calculations were performed on a TI-59 programmable calculator (Texas Instruments, Inc., Dallas, TX).

\section{RESULTS}

One explanation for the ability of unactivated Factor VIII to support Factor $X$ activation after a lag is the hypothesis that the unactivated Factor VIII becomes activated by thrombin or Factor Xa during the lag. I chose to test this hypothesis by studying whether the ability of unactivated Factor VIII to support Factor $\mathrm{X}$ activation could be blocked by specific inhibition of Factor Xa or thrombin. To do these studies, I needed a potent specific inhibitor of thrombin, and another of Factor Xa, that did not inhibit Factor IXa. A series of inhibitors was tested against purified human Factor $\mathrm{IXa}$ in the ${ }^{3} \mathrm{H}-\mathrm{Factor} \mathrm{X}$ activation assay (Table $\mathrm{I}$ ) and

TABLE I

Effect of Inhibitors on Human Factor IXa

\begin{tabular}{ll}
\hline \multicolumn{1}{c}{ Inhibitor $^{\bullet}$} & Degree of Inhibitiont \\
\hline BZA, $2 \mathrm{mM} \S$ & $80 \%$ \\
DAPA, $2.0 \mu \mathrm{M} \S$ & None \\
Hirudin, $450 \mathrm{U} / \mathrm{ml}$ & None \\
IGAA-CK, $1.0 \mu \mathrm{M}$ & None \\
iPr $_{2} \mathrm{PF}, 5 \mathrm{mM}$ & $20 \%$ after $1.5 \mathrm{~h}$ \\
& $100 \%$ after $24 \mathrm{~h}$ \\
PMSF, $4 \mathrm{mM}$ & $100 \%$ after $1 \mathrm{~h}$ \\
STI, $20 \mu \mathrm{g} / \mathrm{ml}$ & None \\
\hline
\end{tabular}

- Each inhibitor, at the concentration indicated, was incubated with human Factor IXa at $37^{\circ} \mathrm{C}$ for $5 \mathrm{~min}$, unless otherwise indicated, and then a subsample was assayed for Factor IXa activity in the ${ }^{3} \mathrm{H}$-Factor $\mathrm{X}$ activation assay.

$\$$ Expressed as a percentage of the control assay of Factor IXa incubated with TBS buffer rather than inhibitor.

\& The inhibitor concentrations listed for (BZA) and DAPA are the concentrations in the final ${ }^{3} \mathrm{H}$-Factor $\mathrm{X}$ activation assay rather than the initial incubation with Factor IXa, since rapid reversibility of inhibitor effect upon dilution into the final assay may be expected. against thrombin and Factor $\mathrm{Xa}$ in the S-2238 and S2222 assays. Factor IXa was not inhibited by DAPA or hirudin at concentrations that gave $90 \%$ or greater inhibition of thrombin and no inhibition of Factor Xa. STI, a rapid and irreversible inhibitor, had no effect on human Factor IXa or thrombin at $20 \mu \mathrm{g} / \mathrm{ml}$ but did inhibit Factor Xa; STI also inhibited Factor IXa at much higher concentrations $(>200 \mu \mathrm{g} / \mathrm{ml})$. IGGA-CK, an irreversible inhibitor, did not inhibit Factor IXa at $1.0 \mu \mathrm{M}$, a concentration which markedly inhibited Factor $\mathrm{Xa}\left(\mathrm{t}_{1 / 2}<20 \mathrm{~s}\right)$ and slightly inhibited thrombin ( $30 \%$ inhibition at $5 \mathrm{~min}$ ). $\mathrm{BZA}, \mathrm{iPr}_{2} \mathrm{PF}$, and PMSF all inhibited Factor IXa.

The lag in Factor $\mathrm{X}$ activation with unactivated Factor VIII was then studied in the presence and absence of DAPA, hirudin, STI, or IGGA-CK. As expected, a lag of 2-4 min occurred before Factor $X$ activation was observed in the presence of unactivated Factor VIII and Factor IXa (Fig. 1A). When DAPA $(0.5 \mu \mathrm{M})$ or hirudin $(50 \mathrm{U} / \mathrm{ml})$ was included in the assay, partial inhibition in the rate of Factor $\mathrm{X}$ activation was observed but without a major change in the lag (Fig. 1B and C). With the inclusion of IGGA-CK, $1.0 \mu \mathrm{M}$, the lag was prolonged, and with STI, $20 \mu \mathrm{g} /$

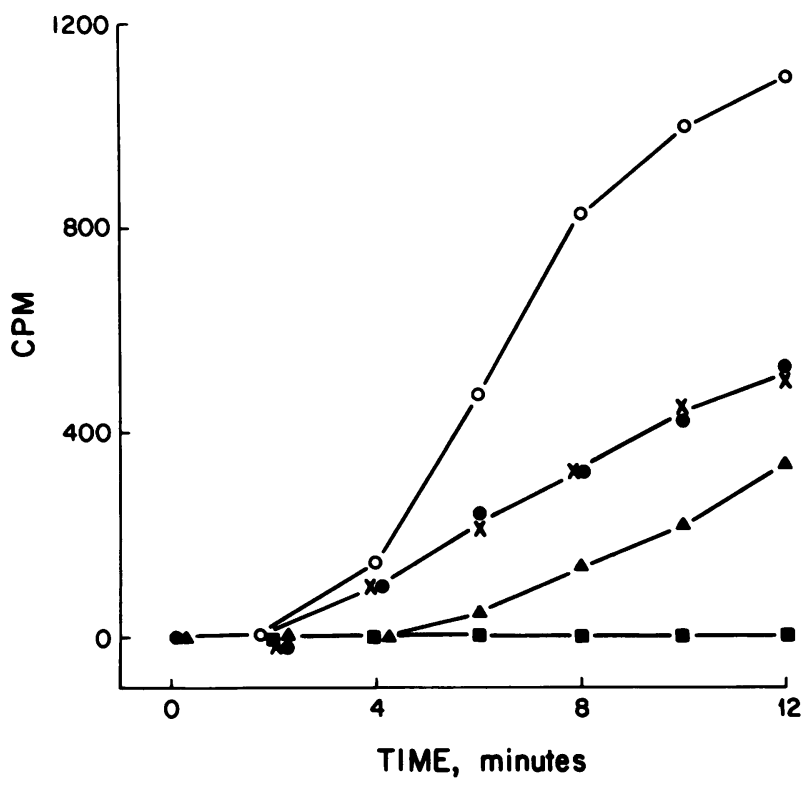

FIgure 1 Effect of inhibitors on the lag in Factor $X$ activation with unactivated Factor VIII. The activation of bovine ${ }^{3} \mathrm{H}$-Factor $\mathrm{X}, 0.2 \mu \mathrm{M}$, was measured as tritiated activation peptide released (average counts per minute of duplicate aliquots, minus base-line counts per minute at zero time) over time in the presence of Factor IXa, $17 \mathrm{nM}$, inosithin, $60 \mu \mathrm{g} / \mathrm{ml}, \mathrm{Ca}^{2+}, 8 \mathrm{mM}$, and (A) unactivated Factor VIII, $4 \mathrm{U} / \mathrm{ml}(\mathrm{O})$ and with the added presence of (B) DAPA, $0.5 \mu \mathrm{M}(\mathrm{X})$, (C) hirudin, $50 \mathrm{U} / \mathrm{ml}$ (๑), (D) IGGA, $1.0 \mu \mathrm{M}$ $(\Delta)$, or (E) STI, $20 \mu \mathrm{g} / \mathrm{ml}(\mathbb{B})$. 
ml, no Factor $X$ activation was observed (Fig. 1D and E). The specificity of these inhibitors was also supported by the observations that STI did not block Factor $\mathrm{X}$ activation when exogenous thrombin was added during the lag, whereas DAPA and hirudin did (Fig. 2). In addition, preincubation of Factor VIII with Factor Xa shortened the lag, and this effect was blocked by STI. It is conceivable that the proposed effect of Factor Xa during the lag (as in Fig. 1A) is not activation of Factor VIII, but rather activation of contaminating prothrombin to thrombin, which then activates Factor VIII. If this were the case, one would expect inhibition of thrombin to prevent subsequent Factor $X$ activation as well as inhibition of Factor $\mathrm{Xa}$, whereas, in fact, thrombin inhibitors did not prevent Factor $\mathrm{X}$ activation, while STI, a Factor $\mathrm{Xa}$ inhibitor, did. When thrombin was measured by subsampling into S-2238 at 0 and $8 \mathrm{~min}$, some thrombin activity $(0.01 \mathrm{U} / \mathrm{ml})$ was detectable by $8 \mathrm{~min}$ in the absence of inhibitors but not in the presence of DAPA or hirudin (as in Fig. $1 B$ and $C$ ). Thus, in the absence of any inhibitors, Factor VIII may be activated by both Factor $\mathrm{Xa}$ and thrombin, and this explains why inhibition of thrombin decreases the rate of Factor $\mathrm{X}$ activation observed. The important point is that only inhibitors of Factor Xa markedly prolonged the lag. This suggests a critical role for Factor $\mathrm{Xa}$ feedback in activating Factor VIII.

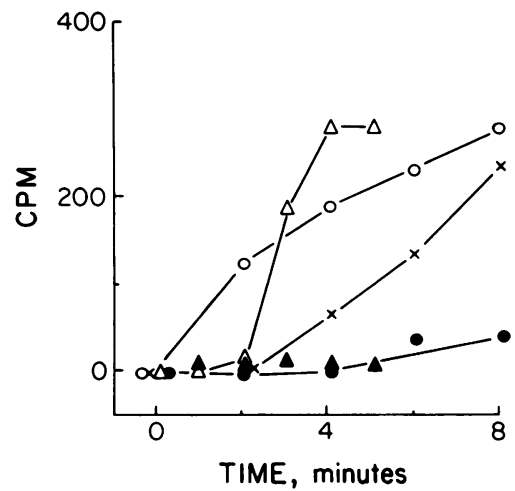

Figure 2 Effect of added thrombin or Factor Xa on the lag in Factor $\mathrm{X}$ activation with unactivated Factor VIII. The activation of human ${ }^{3} \mathrm{H}$-Factor $\mathrm{X}, 0.12 \mu \mathrm{M}$, was measured as tritiated activation peptide released over time (average counts per minute of duplicate aliquots minus a verage counts per minute at zero time), in the presence of (A) unactivated Factor VIII, $4 \mathrm{U} / \mathrm{ml}, \mathrm{Ca}^{2+}, 8 \mathrm{mM}$, inosithin, $60 \mu \mathrm{g} / \mathrm{ml}$, and Factor IXa, $4.6 \mathrm{nM}(\mathrm{X})$; (B) with added Factor Xa, $0.7 \mathrm{nM}$ (incubated with Factor VIII, $\mathrm{Ca}^{2+}$, and inosithin for $2 \mathrm{~min}$ before the addition of Factors $X$ and IXa) (O); (C) with added Factor Xa (as in B) plus STI, $20 \mu \mathrm{g} / \mathrm{ml}()_{\text {); (D) with }}$ STI, $20 \mu \mathrm{g} / \mathrm{ml}$, and thrombin, $0.04 \mathrm{U} / \mathrm{ml}$ (added at the 2min time point during the lag) $(\Delta)$; and (E) with STI, 20 $\mu \mathrm{g} / \mathrm{ml}$, DAPA, $1.0 \mu \mathrm{M}$, hirudin, $100 \mathrm{U} / \mathrm{ml}$, and thrombin, $0.04 \mathrm{U} / \mathrm{ml}$ (added as in D) $(\Delta)$.
Inasmuch as the lag in Factor $\mathrm{X}$ activation appeared to be related to the degree of activation of Factor VIII, I investigated whether the lag could be abolished by optimal activation of Factor VIII. Experiments with various thrombin concentration and incubation times with Factor VIII showed that there was no apparent lag if Factor VIII was incubated with thrombin, 0.5 $\mathrm{U} / \mathrm{ml}$, for $1 \mathrm{~min}$ before the final reactant was added and Factor $\mathrm{X}$ activation measured, regardless which reactant was added last (Fig. 3). The absence of a lag was then measured more precisely by modifying the assay technique so that the zero time point measured experimentally could be compared statistically to the zero time point predicted by extrapolation of the initial rate of Factor $\mathrm{X}$ activation to the $y$ axis (see Methods). The experimentally measured zero time point fell within the 2-SD range of the predicted $y$ axis intercept, i.e., no lag was measurable, whether $\mathrm{Ca}^{2+}$, inosithin, activated Factor VIII, Factor IXa, or Factor X was added last (Table II). This also was true when thrombin-activated platelets were substituted for inosithin

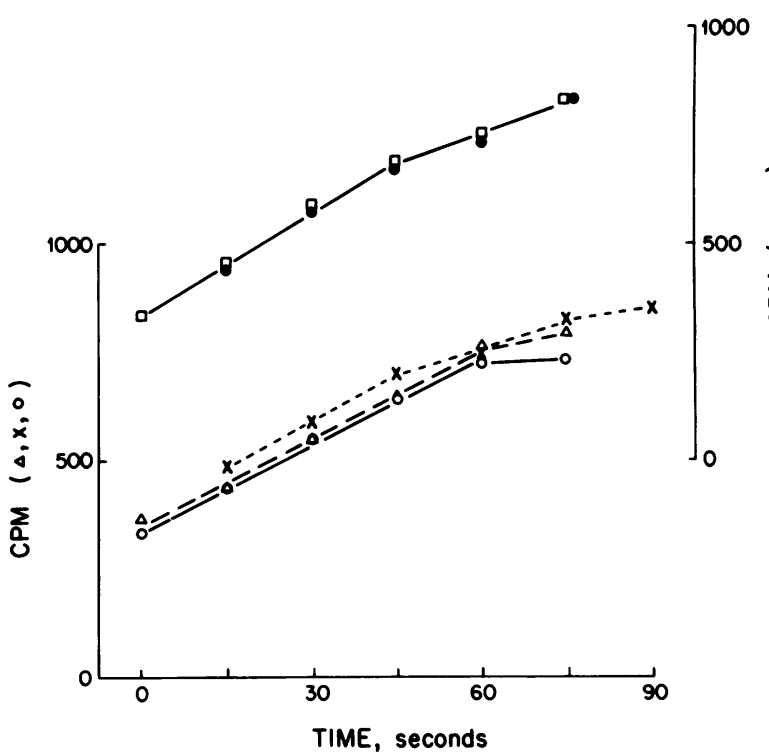

Figure 3 Absence of a lag in Factor $\mathrm{X}$ activation with activated Factor VIII. The activation of bovine ${ }^{3} \mathrm{H}-\mathrm{F}$ actor $\mathrm{X}$ was measured (as in Fig. 1) in the presence of thrombinactivated Factor VIII, with a different reactant added last in each part: Factor IXa, $1.6 \mathrm{nM}(O), \mathrm{Ca}^{2+}, 8 \mathrm{mM}(\triangle),{ }^{3} \mathrm{H}$ Factor X, $0.18 \mu \mathrm{M}(\times)$, Factor VIII, $4 \mathrm{U} / \mathrm{ml}$, preactivated with thrombin, $0.5 \mathrm{U} / \mathrm{ml}(\odot)$, or inosithin, $60 \mu \mathrm{g} / \mathrm{ml}(\square)$. Because the plots superimpose, they were plotted in two separate groups for clarity. The counts per minute measured at zero time represent the baseline trichloroacetic acid-soluble tritium label present in the ${ }^{3} \mathrm{H}$-Factor $\mathrm{X}$ before activation ( $<3.0 \%$ of total counts per minute). The increase in counts per minute over time is linear from zero time (the addition of the final reactant) to $45-60 \mathrm{~s}$, and the slopes of all plots are identical. 
TABLE II

Effect of the Order of Addition of Reactants on the Lag in Factor X Activation

\begin{tabular}{lccc}
\hline $\begin{array}{c}\text { Reactant } \\
\text { added last }\end{array}$ & $\begin{array}{c}\text { Predicted } \\
y \text { intercept }\end{array}$ & $\begin{array}{c}\text { Observed } \\
y \text { intercept }\end{array}$ & Initial rate \\
\hline & $c p m \pm 1$ SD & $c p m^{*}$ & $\begin{array}{c}c p m / s \pm 1 \\
S D\end{array}$ \\
& & & $8.5 \pm 1.0$ \\
Inosithin & $355 \pm 28$ & 350 & $9.7 \pm 2.1$ \\
Factor IXa & $424 \pm 61$ & 404 & $7.7 \pm 1.0$ \\
Ca $^{2+}$ & $375 \pm 15$ & 373 & $8.4 \pm 0.6$ \\
Factor VIII & $335 \pm 14$ & 321 & $9.2 \pm 0.9$ \\
Factor X & $366 \pm 19$ & 362 & \\
\hline
\end{tabular}

- The measured counts per minute at zero time (just before addition of the final reactant), which represents the trichloroacetic acidsoluble tritium label in the ${ }^{3} \mathrm{H}$-Factor $\mathrm{X}$ before activation.

(Table III). These data make it unlikely that there is an ordered time-dependent addition of reactants at the platelet or phospholipid surface, unless the time dependence is $<1-2 \mathrm{~s}$, the detection limit for a lag by these methods. The ability of platelets to support Factor $\mathrm{X}$ activation without a lag requires that the platelets be optimally activated by thrombin just before they are to be used in the Factor $\mathrm{X}$ activation system (see Methods).

Another approach to assessing the role of Factor VIII in Factor $\mathrm{X}$ activation is the determination of the effect on kinetic parameters, such as the $V_{\max }$ and $K_{m}$, of the presence or absence of Factor VIII. The availability of an initial rate assay of Factor $\mathrm{X}$ activation made it possible to determine these parameters by varying Factor $\mathrm{X}$ concentration with constant concentrations of Factor IXa, activated Factor VIII, calcium ions, and phospholipid (or activated platelets). The optimal levels of $\mathrm{Ca}^{2+}$ and phospholipid suspension were determined by titration, and the maximum Factor VIII concentration possible was used, since this was found to approach saturation, that is, nonrate-limiting

TABLE III

Effect of the Order of Addition of Reactants on the Lag in Factor X Activation

\begin{tabular}{llcc}
\hline $\begin{array}{c}\text { Reactant } \\
\text { added last }\end{array}$ & $\begin{array}{c}\text { Predicted } \\
y \text { intercept }\end{array}$ & $\begin{array}{c}\text { Observed } \\
y \text { intercept }\end{array}$ & Initial rate \\
\hline & $c p m \pm 1$ SD & $c p m$ & $c p m / s \pm 1$ SD \\
Platelets & $371 \pm 8$ & 361 & $11.3 \pm 1.4$ \\
Factor IXa & $353 \pm 17$ & 380 & $17.4 \pm 0.9$ \\
Ca $^{2+}$ & $314 \pm 18$ & 327 & $17.3 \pm 0.8$ \\
Factor VIII & $360 \pm 26$ & 325 & $12.2 \pm 0.8$ \\
Factor X & $382 \pm 20$ & 348 & $17.1 \pm 0.9$ \\
\hline
\end{tabular}

conditions. I first studied the species-heterologous system of human Factors IXa and VIII with bovine Factor $\mathrm{X}$ in the presence of $\mathrm{Ca}^{2+}$ and inosithin or thrombinactivated platelets (Fig. 4). The $K_{m}$ and $V_{\max }$ were determined by Lineweaver-Burk plots of the reciprocals of initial rate vs. Factor $X$ concentration. An apparent substrate inhibition occurred at concentrations of Factor $\mathrm{X}>0.26 \mu \mathrm{M}$. Therefore, only the linear portion of the plots (four data points) could be used for the linear regression calculation of the slope and $y$-axis intercept, and the kinetic parameters obtained should be considered estimates. The presence of activated Factor VIII increased the $\mathrm{V}_{\max }$ from 1.1 to 58.8 $\mathrm{pmol} / \mathrm{ml}$ per min, a 54 -fold increase, while the $K_{\mathrm{m}}$ decreased 2.5-fold from 0.91 to $0.36 \mu \mathrm{M}$. When activated platelets were substituted for inosithin in the presence of Factor VIII, the $\mathrm{V}_{\max }$ was essentially identical and the $K_{\mathrm{m}}$ was very similar at $0.28 \mu \mathrm{M}$. A comparison with the absence of Factor VIII is not possible

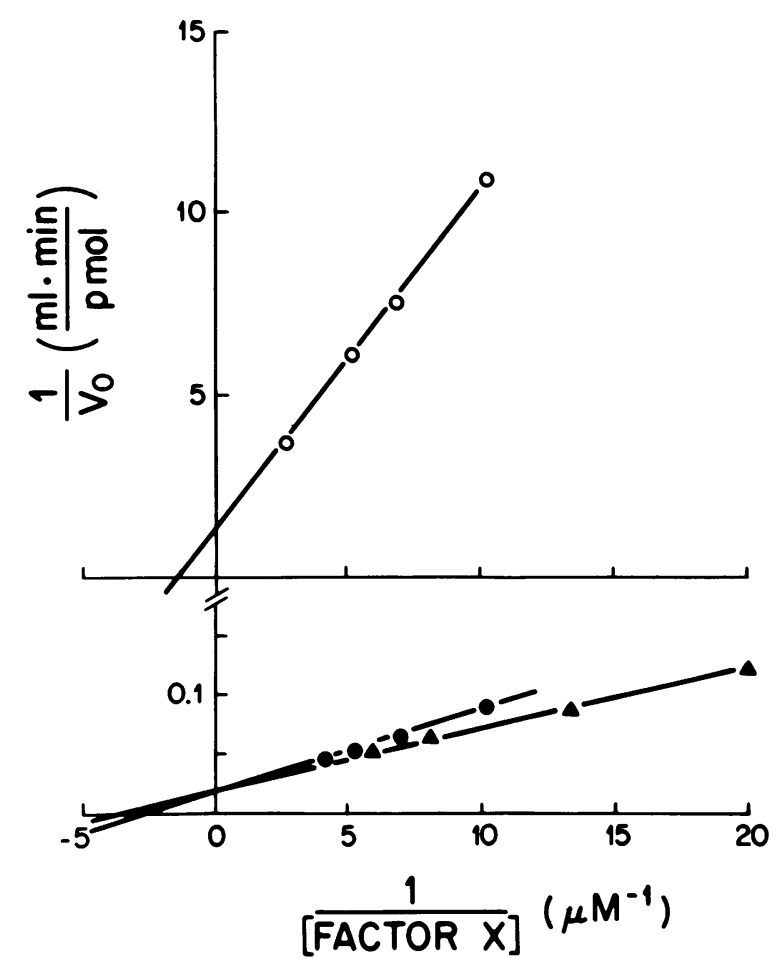

FIGURE 4 Effect of activated Factor VIII on the kinetics of bovine Factor $X$ activation. Lineweaver-Burk plots of the reciprocals of the initial rate of Factor $X$ activation with various Factor $X$ concentrations in the presence of Factor $\mathrm{IXa}, 2.0 \mathrm{nM}, \mathrm{Ca}^{2+}, 8 \mathrm{mM}$, and inosithin, $60 \mu \mathrm{g} / \mathrm{ml}(\mathrm{O})$; inosithin and activated Factor VIII, $4 \mathrm{U} / \mathrm{ml}$ before activation (๑); thrombin-activated platelets, $0.5 \times 10^{6} / \mathrm{mm}^{3}$, and activated Factor VIII (A). Each point is the average of duplicate experiments, and the plots were drawn from the slope and $y$-axis intercept calculated by a linear regression program. 
when platelets are employed, because activated platelets are not stable over the long time courses necessary to measure the slow rates of Factor $X$ activation.

$I$ later repeated these studies with human rather than bovine Factor $X$. The Lineweaver-Burk plots showed that the presence of activated Factor VIII increased the $\mathrm{V}_{\max } 56$-fold, from 0.9 to $50.0 \mathrm{pmol} / \mathrm{ml}$ per $\min$ and that the $K_{\mathrm{m}}$ was decreased 6 -fold, from 0.81 to $0.14 \mu \mathrm{M}$ (Fig. 5). The latter effect was greater than that seen when bovine Factor $X$ was used and decreased the $K_{\mathrm{m}}$ to the range of the plasma concentration of Factor X. Because Lineweaver-Burk plots are inordinately influenced by the lower substrate concentrations, which tend to be the least accurate, I also calculated the $K_{m}$ and $V_{\max }$ from Eadie plots, which are not subject to this problem. The $K_{m}$ and $V_{\max }$ were $0.12 \mu \mathrm{M}$ and $47.3 \mathrm{pmol} / \mathrm{ml}$ per min, respectively, in the presence of Factor VIII and $0.76 \mu \mathrm{M}$ and 0.82 $\mathrm{pmol} / \mathrm{ml}$ per min in its absence. In contrast to the results with bovine Factor $\mathrm{X}$, no substrate inhibition was observed at high concentrations of human Factor $\mathrm{X}$ in the presence of Factor VIII. Studies using activated platelets, instead of PS-PC vesicles, showed that,

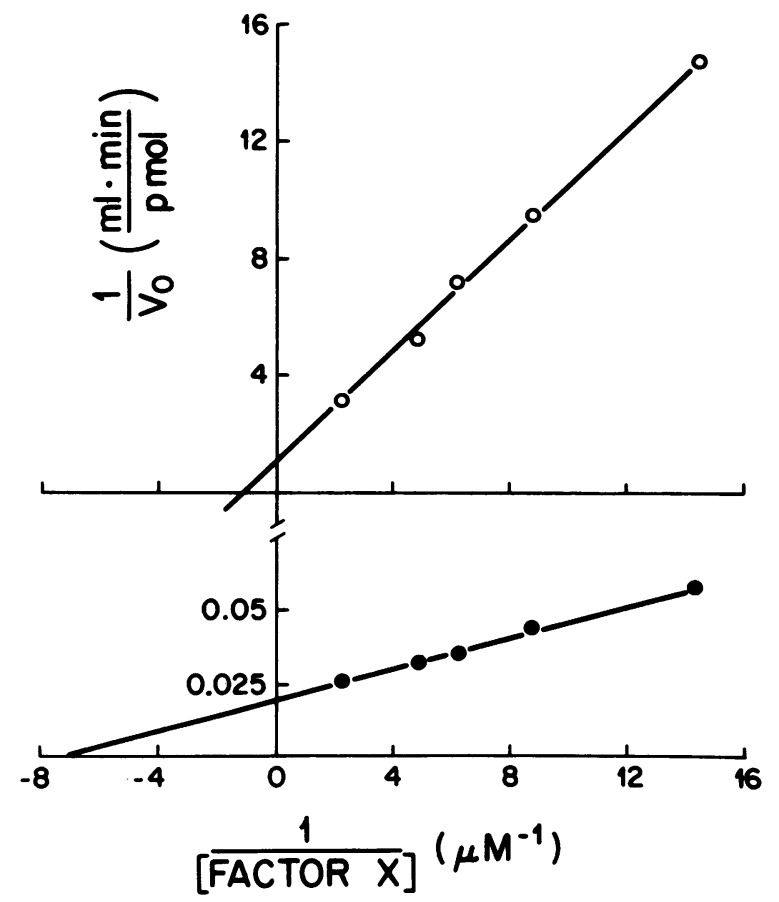

FIGURE 5 Effect of activated Factor VIII on the kinetics of human Factor $X$ activation. Lineweaver-Burk plots of the reciprocals of the initial rate of Factor $X$ activation with various Factor $X$ concentrations in the presence of Factor $\mathrm{IXa}, 2.0 \mathrm{nM}, \mathrm{Ca}^{2+}, 8 \mathrm{mM}$, and PS-PC vesicles, $60 \mu \mathrm{g} / \mathrm{ml}$ (O); and activated Factor VIII, $4 \mathrm{U} / \mathrm{ml}$, before activation (๑). See legend, Fig. 3, for further details. at platelet concentrations of $0.4 \times 10^{6} / \mathrm{mm}^{3}$, platelets supported initial rates of Factor $\mathrm{X}$ activation that usually were less than those with PS-PC. Increasing the platelet concentration to $1.2-2.6 \times 10^{6} / \mathrm{mm}^{3}$ supported initial rates $25-40 \%$ higher than PS-PC or lower concentrations of platelets. When Factor $\mathrm{X}$ concentration was varied from 0.07 to $0.46 \mu \mathrm{M}$ with platelets at 0.4 $\times 10^{6} / \mathrm{mm}^{3}$, linear Lineweaver-Burk plots were obtained with a $\mathrm{V}_{\max }$ of $15.0 \mathrm{pmol} / \mathrm{ml}$ per min and an apparent $K_{\mathrm{m}}$ of $0.36 \mu \mathrm{M}$ (results not shown; experiments performed as with PS-PC, Fig. 5). With a higher concentration of platelets $\left(1.2 \times 10^{6} / \mathrm{mm}^{3}\right)$, both the apparent $K_{\mathrm{m}}$ and $\mathrm{V}_{\max }$ were higher at $1.49 \mu \mathrm{M}$ and 212 $\mathrm{pmol} / \mathrm{ml}$ per min (or $106 \mathrm{~mol} \mathrm{Factor} \mathrm{Xa} / \mathrm{min}$ per $\mathrm{mol}$ Factor IXa). Using this $V_{\max }$, one obtains an estimated turnover number of $1.6 / \mathrm{s}$ for Factor IXa, whereas an estimate of $0.4 / \mathrm{s}$ is obtained with the $\mathrm{V}_{\max }(50 \mathrm{pmol} /$ $\mathrm{ml}$ per $\mathrm{min}$ ) determined in the presence of PS-PC vesicles.

\section{DISCUSSION}

Previous studies have supported the concept that Factor VIII exists in a precursor form that must be activated to act as a cofactor in Factor $\mathrm{X}$ activation (4, 14). The evidence includes the observations that thrombin inhibitors such as hirudin (5) or DAPA (15) block the expression of plasma Factor VIII activity, suggesting that feedback activation of Factor VIII by thrombin is a necessary prerequisite in plasma, at least in vitro. However, Factor Xa also activates Factor VIII in vitro $(6,16)$ and might be as likely a candidate for this role in vivo as thrombin, especially at the platelet surface, which has receptors for both Factors $\mathrm{Xa}$ and thrombin $(17,18)$. The interpretation of previous studies must be cautious because of the relative nonspecificity of clotting assays $(5,13)$, the controversy as to whether hirudin inhibits Factor IXa as well as thrombin $(5,19-21)$ and the difficulty in proving whether a zymogenlike form of Factor VIII has no activity vs. a small degree of activity $(4,14)$. Studies using an initial-rate assay of ${ }^{3} \mathrm{H}$-Factor $\mathrm{X}$ activation $(4,15)$ have an advantage over clotting assays or chromogenic assays in that the effect of Factor VIII or Factor IXa on the isolated, forward rate of Factor $X$ activation can be studied without the potential confusion of feedback reactions if potent inhibitors of thrombin and/or Factor $\mathrm{Xa}$ are included. With this method, $\mathrm{I}$ have shown that hirudin does not inhibit Factor IXa. It is possible that other investigators $(19,20)$ interpreted inhibition of thrombin activation of Factor VIII by hirudin as inhibition of Factor IXa. I also found that Factor IXa is inhibited slowly by $\mathrm{iPr}_{2} \mathrm{PF}(5 \mathrm{mM})$. Other investigators found no inhibition of Factor IXa after a 1-h incubation with $5 \mathrm{mM} \mathrm{iPr}_{2} \mathrm{PF}$ under somewhat dif- 
ferent conditions (12). This may not represent a major disagreement with my data, which would predict a $10-15 \%$ inhibition at $1 \mathrm{~h}$; such a small difference may be difficult to demonstrate, depending on the accuracy of the assay.

The lag in Factor $\mathrm{X}$ activation in the presence of unactivated Factor VIII was studied in the presence of specific inhibitors of Factor Xa or thrombin that did not inhibit human Factor IXa. Thrombin inhibition by DAPA (22) or hirudin had some effect on the rate of Factor X activation but did not prolong the lag; the effect on the rate was probably due to inhibition of a trace of contaminating thrombin or thrombin-activated Factor VIII. In contrast, inhibition of Factor Xa markedly prolonged the lag. These studies support the conclusion that unactivated Factor VIII has no cofactor activity and that activation of Factor VIII by Factor $\mathrm{Xa}$ is an important reaction. When Factor VIII was optimally preactivated by thrombin, no lag occurred, whether inosithin or activated platelets were used. This data weighs against the hypothesis that a time-dependent ordering of reactants is obligatory at the platelet or phospholipid surface. However, in vivo some lag might occur while activation of both Factor VIII and platelets proceeds at a site of vessel injury.

I was unable to demonstrate any significant ability of unactivated platelets to support Factor $\mathrm{X}$ activation. Thrombin-treated platelets did support Factor X activation, an effect which was blocked by prostaglandin $E_{1}$, although prostaglandin $E_{1}$ has no effect on Factor VIII activation by thrombin. Kane et al. (23) found that unactivated platelets, in the presence of DAPA and preactivated Factor $\mathrm{Va}$, bind as much Factor $\mathrm{Xa}$ as activated platelets. The same laboratory had previously shown that the rate of thrombin formation was directly proportional to the platelet concentration when the Factor Xa binding sites were saturated (17). It is therefore possible that unactivated platelets support prothrombin activation but not Factor $\mathrm{X}$ activation. I was unable to perform experiments with unactivated platelets in DAPA similar to those of Kane et al., because DAPA causes an immediate, marked decrease in preactivated Factor VIII (16) and thus is not useful to separate the effects of thrombin on platelets vs. Factor VIII. The fact that thrombin-treated platelets served as an effective substitute for phospholipid cofactor in Factor $\mathrm{X}$ activation in vitro supports the likelihood that Factor $X$ activation occurs at the stimulated platelet surface in vivo.

I also investigated a kinetic approach to evaluating the mechanism of cofactor activity of Factor VIII. The apparent $K_{\mathrm{m}}$ and $\mathrm{V}_{\max }$ were determined in the presence and absence of activated Factor VIII, with various Factor $\mathrm{X}$ concentrations. When bovine Factor $\mathrm{X}$ was employed, linear Lineweaver-Burk plots were ob- tained, except at high concentrations of Factor $\mathrm{X}$, in the presence of Factor VIII (Fig. 4). This apparent substrate inhibition has been reported by Brown et al. (24), but they did not evaluate Factor $X$ activation in the absence of Factor VIII. In my studies this nonlinearity did not occur in the absence of Factor VIII, making it unlikely that a contaminating Factor IXa inhibitor or second enzyme was present in the Factor $\mathrm{X}$ preparation. A contaminant in the Factor VIII preparation is also unlikely, because no substrate inhibition occurred with human Factor $X$ in the presence of the same human Factor VIII preparation (Fig. 5). For bovine Factor $\mathrm{X}$, the presence of activated Factor VIII had a major effect on the $V_{\max }$, increasing it 54-fold, and a lesser effect on the $K_{\mathrm{m}}$, decreasing it 2.5-fold. The $K_{\mathrm{m}}$ in the presence of Factor VIII $(0.36 \mu \mathrm{M})$ was similar to that measured in dilute bovine plasma, 0.39 $\mu \mathrm{M}$ (25). A major effect on the $\mathrm{V}_{\max }$ for bovine Factor $\mathrm{X}$ in the presence of bovine Factor VIII has also been reported by van Dieijen et al. (26), who used a chromogenic substrate assay for Factor Xa generation. They also showed that the $K_{\mathrm{m}}$ is highly dependent on the phospholipid concentration, and thus this value should be considered an apparent $K_{\mathrm{m}}$. In contrast to bovine Factor X, the presence of activated Factor VIII had a major effect on the $K_{m}$ for human Factor $\mathrm{X}$, decreasing it sixfold to $0.14 \mu \mathrm{M}$, and a similar large effect on the $\mathrm{V}_{\max }$, increasing it 56-fold. The decrease in $K_{\mathrm{m}}$ to the plasma concentration of Factor X $(\sim 0.14$ $\mu \mathrm{M})$ suggests that this effect of activated Factor VIII may be of physiologic significance, since changes in plasma Factor $X$ concentration would be expected to have a major effect on the rate of Factor $\mathrm{X}$ activation. All of the kinetic data may be affected by the presence of large amounts of von Willebrand factor in the human Factor VIII preparation, purified by the presently available techniques. Recent data for bovine Factor VIII demonstrate that separation of the von Willebrand factor can be achieved, with marked increase in purity of the Factor VIII (6). If this method is successfully applied to human Factor VIII, it will be interesting to study the kinetic effect of Factor VIII in the absence of von Willebrand factor.

An isolated effect of decreasing the $K_{m}$, as with phospholipid $(26,27)$, suggests that the cofactor mechanism involves localization of substrate in proximity to the enzyme. The effect of activated Factor VIII on both the $K_{m}$ and $V_{\max }$ may be explained by a number of mechanisms. For example, Factor VIII could increase the proteolytic efficiency of Factor IXa by changing the conformation or effective concentration of Factor IXa at the platelet surface, or by improving the substrate conformation. These studies suggest a hypothesis of Factor VIII function in which Factor VIII, activated at the surface of stimulated platelets, then potentiates 
Factor X activation by binding Factor IXa or Factor $\mathrm{X}$ at the platelet surface in a fashion that promotes a catalytically efficient interaction between the two. Such a mechanism is also suggested by the demonstration that activated Factor $\mathrm{V}$ acts as a receptor for Factor $\mathrm{Xa}$ on platelets and promotes prothrombin activation $(17,23)$ and that activated bovine Factor $V$ has a major effect on the $V_{\max }$ of prothrombin activation (28). Whether a similar mechanism for Factor VIII function can be demonstrated conclusively remains to be seen; current studies in this laboratory are directed to this goal.

\section{ACKNOWLEDGMENTS}

I want to thank Penny Hausser, Rose Hsieh, and Jani Kohut for their expert technical assistance, and Jennifer Floyd and Vesta Carucci for typing the manuscript. I also want to thank Dr. Jolyon Jesty for the weighted least-squares program used in the lag studies and Dr. Barry Coller for reading the manuscript.

These studies were supported by research funds from Veterans Administration and by National Institutes of Health grant HL 24893.

\section{REFERENCES}

1. Østerud, B., and S. I. Rapaport. 1970. Synthesis of intrinsic factor $\mathrm{X}$ activator. Inhibition of the function of formed activator by antibodies to factor VIII and to factor IX. Biochemistry 9: 1854-1861.

2. Fujikawa, K., M. H. Coan, M. E. Legaz, and E. W. Davie. 1974. The mechanism of activation of bovine factor $X$ (Stuart factor) by intrinsic and extrinsic pathways. Biochemistry. 13: 5290-5299.

3. Suomela, H., M. Blomback, and B. Blomback. 1977. The activation of factor $X$ evaluated by using synthetic substrates. Thromb. Res. 1: 267-281.

4. Hultin, M. B., and Y. Nemerson. 1978. Activation of factor X by factors IXa and VIII; a specific assay for factor IXa in the presence of thrombin-activated factor VIII. Blood. 52: 928-940.

5. Østerud, B., S. I. Rapaport, S. Schiffman, and M. M. Y. Chong. 1971. Formation of intrinsic factor-X-activator activity, with special reference to the role of thrombin. Br. J. Haematol. 21: 643-660.

6. Vehar, G. A., and E. W. Davie. 1980. Preparation and properties of bovine factor VIII (antihemophilic factor). Biochemistry. 19: 401-410.

7. Weber, K., and M. Osborn. 1969. The reliability of molecular weight determinations by dodecyl sulfate-polyacrylamide gel electrophoresis. J. Biol. Chem. 244: 4406-4412.

8. Kisiel, W., L. H. Ericsson, and E. W. Davie. 1976. Proteolytic activation of protein $\mathrm{C}$ from bovine plasma. Biochemistry. 15: 4893-4900.

9. Hultin, M. B. 1979. Activated clotting factors in factor IX concentrates. Blood. 54: 1028-1038.

10. Silverberg, S. A., Y. Nemerson, and M. Zur. 1977. Kinetics of the activation of bovine coagulation factor $X$ by components of the extrinsic pathway. J. Biol. Chem 252: 8481-8488.

11. Jesty, J. 1979. Dissociation of complexes and their derivatives formed during inhibition of bovine thrombin and activated factor $\mathrm{X}$ by antithrombin III. J. Biol. Chem. 254: 1044-1049.

12. DiScipio, R. G., K. Kurachi, and E. W. Davie. 1978 Activation of human Factor IX (Christmas factor). $J$. Clin. Invest. 61: 1528-1538.

13. Valdorf-Hansen, J. F., and M. B. Zucker. 1971. Effect of temperature and inhibitors on serotonin $-{ }^{14} \mathrm{C}$ release from human platelets. Am. J. Physiol. 220: 105-111.

14. Switzer, M. E. P., S. V. Pizzo, and P. A. McKee. 1979. Is there a precursive, relatively procoagulant-inactive form of normal antithrombin factor (factor VIII)? Blood. 54: 916-927.

15. Marx, G. 1980. Radiometric assay of factor VIII in plasma: requirement for thrombin-activation. Fed. Proc. 39: 1895.

16. Hultin, M., and J. Jesty. 1981. The activation and inactivation of human factor VIII by thrombin: effect of inhibitors of thrombin. Blood. 57: 476-482.

17. Miletich, J. P., C. M. Jackson, and P. W. Majerus. 1977 Properties of the factor $\mathrm{X}_{\mathrm{a}}$ binding site on human platelets. J. Biol. Chem. 253: 6908-6916.

18. Shuman, M. A., D. M. Tollefsen, and P. W. Majerus. 1975. The binding of human and bovine thrombin to human platelets. Blood. 47: 43-54.

19. Pitlick, F. A., R. L. Lundblad, and E. W. Davie. 1969. The role of heparin in intrinsic blood coagulation. $J$. Biomed. Mater. Res. 3: 95-106.

20. Neal, G. G., and S. I. Chavin. 1979. The role of factors VIII and IX in the activation of bovine blood coagulation factor X. Thromb. Res. 16: 473-484.

21. Brown, J. E., R. F. Baugh, and C. Hougie. 1980. The inhibition of the intrinsic generation of activated factor $X$ by heparin and hirudin. Thromb. Res. 17: 267-272.

22. Nesheim, M. E., F. G. Prendergast, and K. G. Mann. 1979. Interactions of a fluorescent active-site-directed inhibitor of thrombin: dansylarginine $\mathrm{N}$-(3-ethyl-1,5pentanediyl)amide. Biochemistry. 18: 996-1003.

23. Kane, W. H., M. J. Lindhout, C. M. Jackson, and $P$. W. Majerus. 1980. Factor $\mathrm{V}_{\mathrm{a}}$-dependent binding of factor $\mathrm{X}_{\mathrm{a}}$ to human platelets. J. Biol. Chem. 255: 11701174 .

24. Brown, J. E., R. F. Baugh, and C. Hougie. 1978. Substrate inhibition of the intrinsic generation of activated factor X (Stuart factor). Thromb. Res. 13: 893-900.

25. Steinberg, M., S. Silverberg, J. Jesty, and Y. Nemerson. 1980. Kinetics of activation of factors IX and $X$ in bovine plasma. Fed. Proc. 39: 1894.

26. van Dieijen, G., G. Tans, J. Rosing, and H. C. Hemker. 1981. The role of phospholipid and factor $\mathrm{VIII}_{\mathrm{a}}$ in the activation of bovine factor X. J. Biol. Chem. 256: 34333442 .

27. Kosow, D. P., B. Furie, and H. Forastieri. 1974. Activation of factor $\mathrm{X}$ : kinetic properties of the reaction. Thromb. Res. 4: 219-227.

28. Rosing, J., G. Tans, J. W. P. Govers-Riemslag, R. F. A. Zwaal, and H. C. Hemker. 1980. The role of phospholipids and factor $\mathrm{V}_{\mathrm{a}}$ in the prothrombinase complex. $J$. Biol. Chem. 255: 274-283. 